\title{
A Study on Protein, in vitro Protein Digestibility, Antioxidant Activity and Total Polyphenol Content of Horsegram Varieties
}

\author{
Aishwarya V. Patil* and B. Kasturiba \\ Department of Food Science and Nutrition, College of Community Science, University of \\ Agricultural Sciences, Dharwad, Karnataka, India \\ *Corresponding author
}

\section{A B S T R A C T}

\section{Keywords}

Horsegram Antioxidant Activity and Total Polyphenol

Article Info

Accepted:

15 January 2019

Available Online:

10 February 2019

\begin{abstract}
Horsegram (Macrotyloma uniflorum (Lam) Verdc.) is minor legume, which belongs to family Fabaceace. It is a potential grain legume having excellent nutritional quality with better resilience property to adapt harsh environment conditions. Seven released varieties and five advanced breeding lines of horsegram were procured from All India Coordinated Research Project - Dryland Agriculture, Vijayapur. The horsegram were assessed for crude protein, in vitro protein digestibility, antioxidant activity and total polyphenols content. There was no significant difference among the varieties for crude protein, whereas in vitro protein digestibility, antioxidant activity and total polyphenol content varied significantly $(\mathrm{p} \leq 0.01)$ among the varieties. The protein content, in vitro protein digestibility, antioxidant activity and total polyphenols content ranged from 23.10-28.21 g/100 g, 50.80-67.80 per cent, 80.24-89.41 per cent DPPH and 2.35-3.61 mgGAE/g respectively.
\end{abstract}

\section{Introduction}

Food legumes constitute an important component of diet across the world and are the next important food crops after cereals. As a result, pulses have significant cultural and historical significance (Roy et al., 2010). They play a vital role in sustainable agriculture and a key source of dietary nutrients for many of people in the developing countries. The legumes belongs to family Leguminosae (Fabaceace) which are eaten directly by humans, usually in the form of mature dry seeds, but sometimes in the form of immature seeds attached in the pod.
Dehulled pulses, also known as dals, are famous for their high quality protein content and are considered as meat substitutes for people in less developed countries. Legumes are good sources of protein that are cheap and widely available for human consumption. They are staple foods for many people in different parts of the world. Legume seeds have an average of twice as much protein as cereals and nutritive value of the proteins are usually high. They are widely cultivated and distributed in Africa, Asia, West Indies, Latin America and India. The legumes can be grown in marginal soils and in arid or semi arid regions. Their deep penetrating root 
system enables them to withstand moisture stress (Bhokre and Joshi, 2015). Pulses are popular because animal protein is expensive and it is not consumed due to religious beliefs and moral values. In Indian diet, cereals (deficient in lysine) are usually eaten with pulses (poor source of methionine) to make a complete protein diet. Apart from being an important source of macro nutrients (carbohydrate, protein, fiber) and micro nutrients (calcium, magnesium, zinc, iron, potassium, and phosphorus), health benefits of consuming legumes are also related to the amount of dietary fiber and polyphenol content. There are a number of epidemiological studies related to high phenolic content in legumes for fewer incidences of diseases such as cancer, aging, diabetes, and heart diseases, which is related to the consumption of legumes (Kris-Etherton et al., 2002). The dominant phenolic compounds present in leguminous seeds are flavanoids, phenolic acids, and procyanidins (Amarowicz and Pegg, 2008). They are also an important source of antioxidants, where they exhibit anti-inflammatory, cardioprotective, anti-microbial, vasodilatory effects, and anti-allergic properties. Presently, attention towards underutilized legumes is increasing for finding new alternative sources to meet the ever increasing demand for vegetable protein (Bhartiya et al., 2015). In developing countries, primarily a handful of conventional legumes are dominating the production and market chains and are playing a crucial role in eradicating protein energy malnutrition still, some of the underutilized indigenous legumes like, horse gram has a great significance in the nutritional security of rural, tribal and underprivileged masses.

Among legumes, horsegram [Macrotyloma uniflorum (Lam.) Verdc.] is a minor legume crop of India and is of good nutritional quality (Pal et al., 2015). It belongs to family Fabaceace, has potential nutritional and remedial properties with better climate resilience to adapt to harsh environmental conditions. It is one of the most important under exploited food legume being grown almost all over the world including temperate and sub-tropical regions encompassing the countries particularly, India, China, Philippines, Bhutan, Pakistan, Sri Lanka and Australia (Durga, 2016; Bhartiya et al., 2015). In India it is most extensively grown pulse in the south, the maximum area being in Andhra Pradesh, Karnataka and Tamil Nadu. It is grown mainly to furnish feed and fodder for cattle and horse. It makes excellent hay and is suitable as green manure. Antioxidant is significant for the defense mechanism in the human body and helps in the management with oxidative stress due to reactive oxygen species. Presently people are more concerned about antioxidant properties of food. This is primarily due to its protective action against harmful free radicals and thus reduces the risk of cardiovascular diseases and cancer, prevents oxidative damage of lipids and lowdensity lipoprotein. Antioxidants that exist, improve food quality and safety by blocking lipid peroxide. Horsegram contains a potential antioxidant activity and phenolic content. Hence the present study is undertaken to assess the protein, in vitro protein digestibility, total polyphenols content and antioxidant activity of horsegram varieties.

\section{Materials and Methods}

\section{Procurement of the horsegram varieties}

Twelve varieties of horsegram were procured from AICRP for Dryland Agriculture RARS, Vijayapur, Karnataka. Out of twelve varieties five were advanced breeding line of University of Agricultural Sciences, Dharwad, while remaining seven varieties were released for cultivation across different regions. The details regarding the samples are given in Table 1. The samples were cleaned before the study was carried out. All estimations were carried out in triplicates. 


\section{Crude protein}

The crude protein was estimated in Kelplus instrument of Pelican and crude protein was expressed in per cent $(\%)$ and calculated by multiplying with a factor of 6.25 (Anon., 2005).

Crude protein $(\%)=$

(Titre value - Blank) $\times$ Normality of $\mathrm{HCl} \times$ $14.007 \times 6.25$

Weight of the sample $(\mathrm{g})$

In vitro protein digestibility of horsegram varieties

Sample containing $100 \mathrm{mg}$ of protein was treated with $0.1 \mathrm{~N} \mathrm{HCl}$ containing $19.5 \mathrm{mg}$ of pepsin at $37{ }^{\circ} \mathrm{C}$ for 3 hours. $0.5 \mathrm{~N}$ sodium hydroxide was used to neutralize the contents. After neutralizing phosphate buffer $(25 \mathrm{ml})$ containing pancreatin $(6 \mathrm{mg})$ was added and incubated at $37^{\circ} \mathrm{C}$ for 24 hours.

Then, volume was made upto $100 \mathrm{ml}$ using distilled water and aliquot of $50 \mathrm{ml}$ was treated with 10 per cent trichloroacetic acid and left overnight for precipitation. The suspended contents were centrifuged and the residue was analysed for protein by microkjeldahl method (Moulishwar et al., 1993). The amount of protein digested was calculated using the formula,

Digested protein $=$

Total protein - Undigested protein

Total protein

\section{Antioxidant activity of horsegram varieties}

The principle used for estimating antioxidant activity was DPPH (2,2-diphenyl-1-picryl- hydrazyl) free radical method is an antioxidant assay based on electron-transfer that produced violet solution in methanol. $1 \mathrm{~g}$ of defatted sample was refluxed for half an hour using $10 \mathrm{ml}$ methanol, the extract was centrifuged and supernatant was used for estimation. $1 \mathrm{ml}$ of extract was mixed with $0.05 \mathrm{mg} / \mathrm{ml}$ of DPPH and mixed well to stand at room temperature at $30 \mathrm{~min}$. Then the absorbance was measured at $517 \mathrm{~nm}$ (Dorman et al., 2004).

The DPPH is estimated by,

DPPH scavenging effect $(\%)=\left(\mathrm{A}_{0}-\mathrm{A}_{1}\right) \times 100$

Where, $A_{o}$ was the absorbance of the negative control and $A_{1}$ was the absorbance of reaction mixture or standards.

\section{Polyphenol content of horsegram varieties}

Total polyphenols was estimated using FolinCiocalteau reagent. Blue coloured complex was formed in alkaline medium when phenols reacted with phosphomolybdic acid in FolinCiocalteau reagent (Sadashivam and Manicham, 2008).

\section{Results and Discussion}

Table 2 depicts the crude protein among the horsegram varieties. There was no significant difference in crude protein among the varieties. Protein content ranged from 23.10$28.21 \mathrm{~g} / 100 \mathrm{~g}$. Highest protein content was observed in VHG44 (28.21 g/100 g), followed by VHG13-01 (27.68 g/100 g) and VHG15 $(27.02 \mathrm{~g} / 100 \mathrm{~g})$ and DHG01 had lowest protein content. On comparison of proximate composition of released varieties and advanced breeding lines of horsegram, crude protein varied significantly $(\mathrm{p} \leq 0.01)$ between released varieties and advanced breeding lines of horsegram varieties. Crude protein was higher in advanced breeding lines than released varieties (Table 3). The study conducted by Bhokre et al., (2015) showed 
similar values for crude protein. The study conducted by Hiremath et al., (2000) recorded slightly lower values for crude protein. The study conducted by Bhokre et al., (2015) showed similar values for crude protein. The reason attributed to this may be due to locality, varietal differences, agronomical condition in which they are grown and climatic conditions.

The in vitro protein digestibility is presented in Figure 1. The in vitro protein digestibility varied significantly $(\mathrm{p} \leq 0.01)$ among the varieties. The in vitro protein digestibility among varieties ranged from 50.80-67.80 per cent. VHG44 (67.80 \%) had highest in vitro protein digestibility followed by VHG13-01 $(65.67 \%)$ and VHG938 (62.57\%). AK44 $(50.80 \%)$ had lowest in vitro protein digestibility among the horsegram varieties. Table 4 depicted the Comparison of in vitro protein digestibility between the released and advanced breeding lines of horsegram. There was a significant difference $(\mathrm{p} \leq 0.01)$ between the released and advanced breeding lines of horsegram.
Higher values of in vitro protein digestibility was observed in advanced breeding lines (63.62 \%), when compared to released varieties $(56.05 \%)$ of horsegram varieties. The study conducted by Khatoon and Prakash (2006) showed similar results and Sreerama $e t$ al, (2008) showed lower values of in vitro protein digestibility. This may be due to the presence of antinutritional factors.

Figure 2 depicts the total antioxidant activity of horsegram varieties. Total antioxidant activity varied significantly $(\mathrm{p} \leq 0.01)$ among the varieties. The total antioxidant activity ranged from 80.24-89.41 per cent DPPH.

Lowest antioxidant activity was observed in AK42 (80.24 per cent DPPH). The varieties VHG44 (89.41 per cent DPPH) had highest total antioxidant activity followed by VHG935 (89.28 per cent DPPH) and CRHG22 (87.71 per cent DPPH). Comparison of total antioxidant activity of released varieties and advanced breeding lines of horsegram is presented in Table 5 .

Table.1 Horsegram varieties selected for study

\begin{tabular}{|l|l|}
\hline \multicolumn{2}{|c|}{ Horsegram varieties } \\
\hline \multicolumn{1}{|c|}{ Released varieties } & \multicolumn{1}{c|}{ Advanced breeding lines } \\
\hline AK 42- ARJIA KULTHI 42 & $\begin{array}{l}\text { VHG 13-01- VIJAYAPUR HORSEGRAM - } \\
13-01\end{array}$ \\
\hline AK 44- ARJIA KULTHI 44 & VHG 15- VIJAYAPUR HORSEGRAM -15 \\
\hline CRHG 22- CRIDA HORSEGRAM 22 & VHG 44- VIJAYAPUR HORSEGRAM -44 \\
\hline CRHG 23- CRIDA HORSEGRAM 23 & VHG 935- VIJAYAPUR HORSEGRAM -935 \\
\hline $\begin{array}{l}\text { DHG 01- DANTEWADA } \\
\text { HORSEGRAM 01 }\end{array}$ & $\begin{array}{l}\text { VHG 938-- VIJAYAPUR HORSEGRAM - } \\
\text { GPM 06- GERMPLASM SELECTION } \\
\text { 06 }\end{array}$ \\
\hline $\begin{array}{l}\text { KBHG 01- KARNATAKA BIJAPUR } \\
\text { HORSEGRAM- 01 }\end{array}$ & \\
\hline
\end{tabular}


Table.2 Crude protein of horsegram varieties $(\mathrm{g} / 100 \mathrm{~g})$

\begin{tabular}{|l|c|}
\hline \multicolumn{1}{|c|}{ Varieties } & Crude protein \\
\hline Released Varieties & $25.23 \pm 0.05^{\mathrm{c}}$ \\
\hline AK42 & $25.43 \pm 0.80^{\mathrm{c}}$ \\
\hline AK44 & $23.10 \pm 1.21^{\mathrm{e}}$ \\
\hline DHG01 & $23.36 \pm 0.23^{\mathrm{de}}$ \\
\hline GPM06 & $24.63 \pm 0.45^{\mathrm{cd}}$ \\
\hline KBHG01 & $24.83 \pm 0.58^{\mathrm{cd}}$ \\
\hline CRHG22 & $23.66 \pm 0.58^{\mathrm{de}}$ \\
\hline CRHG23 & $27.68 \pm 0.80^{\mathrm{a}}$ \\
\hline Advanced breeding lines & $27.02 \pm 0.53^{\mathrm{ab}}$ \\
\hline VHG13-01 & $28.21 \pm 0.49^{\mathrm{a}}$ \\
\hline VHG15 & $26.93 \pm 0.62^{\mathrm{ab}}$ \\
\hline VHG44 & $26.13 \pm 0.12^{\mathrm{bc}}$ \\
\hline VHG935 & \\
\hline VHG938 & $25.52 \pm 0.78$ \\
\hline Mean \pm SD & 0.47 \\
\hline S.Em. \pm & $\mathrm{NS}$ \\
\hline C.D. & 21.94 \\
\hline F value & \\
\hline
\end{tabular}

Note: Values are mean of three replications, S.Em.: Standard error of mean, C.D.: Critical difference, NS-Non significant

Table.3 Comparison of crude protein $(\mathrm{g} / 100 \mathrm{~g})$ of released varieties and advanced breeding lines of horsegram varieties

\begin{tabular}{|l|c|}
\hline Varieties & Crude protein (\%) \\
\hline Released varieties & $24.51 \pm 1.42$ \\
\hline Advanced breeding lines & $27.10 \pm 0.93$ \\
\hline t value & $6.57^{* *}$ \\
\hline
\end{tabular}

Note: Values are mean of three replications, **Significant @ 1\%,

Table.4 Comparison of in vitro protein digestibility of released varieties and advanced breeding lines of horsegram varieties

\begin{tabular}{|l|c|}
\hline \multicolumn{1}{|c|}{ Varieties } & In vitro protein digestibility \\
\hline Released varieties & $56.05 \pm 3.91$ \\
\hline Advanced breeding lines & $63.62 \pm 3.24$ \\
\hline t value & $6.07^{* *}$ \\
\hline
\end{tabular}

Note: Values are mean of three replications, **Significant @1\%

Table.5 Comparison of antioxidant activity of released varieties and advanced breeding lines of horsegram varieties

\begin{tabular}{|l|c|}
\hline \multicolumn{1}{|c|}{ Varieties } & Scavenging activity (\%) \\
\hline Released varieties & $83.23 \pm 2.92$ \\
\hline Advanced breeding lines & $87.52 \pm 1.72$ \\
\hline t value & $5.38^{* *}$ \\
\hline
\end{tabular}

Note: Values are mean of three replications, **Significant @ 1\% 
Table.6 Comparison of total phenolic content of released varieties and advanced breeding lines of horsegram varieties

\begin{tabular}{|l|c|}
\hline \multicolumn{1}{|c|}{ Varieties } & Total polyphenols $(\mathbf{m g} / \mathbf{g})$ \\
\hline Released varieties & $2.85 \pm 0.53$ \\
\hline Advanced breeding lines & $2.66 \pm 0.50$ \\
\hline t value & $\mathrm{NS}$ \\
\hline
\end{tabular}

Note: Values are mean of three replications, NS-Non significant

Table.7 Correlation between antioxidant activity and total polyphenols content of horsegram varieties

\begin{tabular}{|l|c|c|}
\hline & Antioxidant activity & Total polyphenols \\
\hline Antioxidant activity & 1 & 0.034 \\
\hline Total polyphenol & & 1 \\
\hline
\end{tabular}

Table.8 Correlation between antioxidant activity and protein content of horsegram varieties

\begin{tabular}{|l|c|c|}
\hline & Antioxidant activity & Protein \\
\hline Antioxidant activity & 1 & $0.480^{* *}$ \\
\hline Protein & & 1 \\
\hline
\end{tabular}

Fig.1

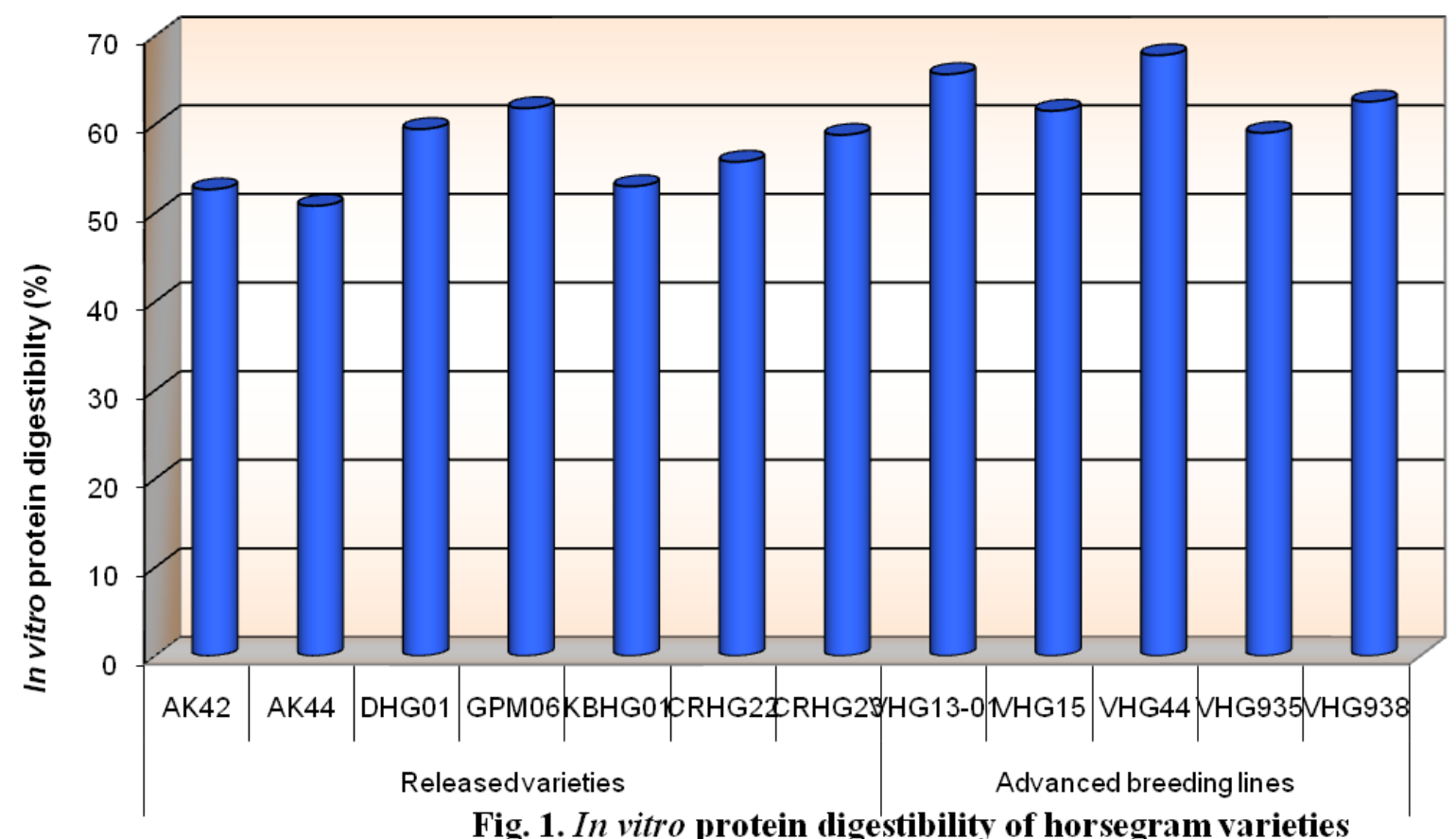


Fig.2

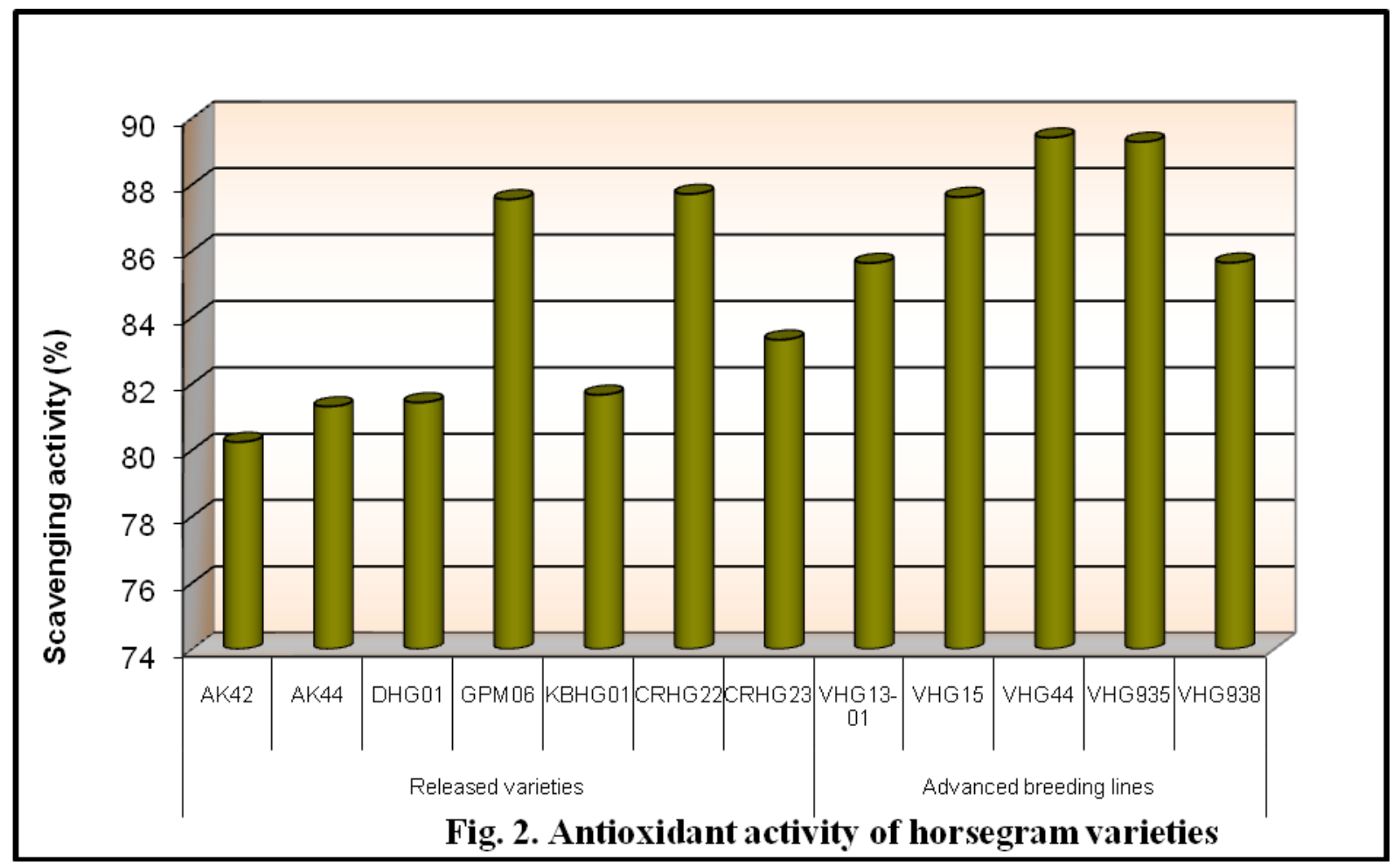

Fig.3

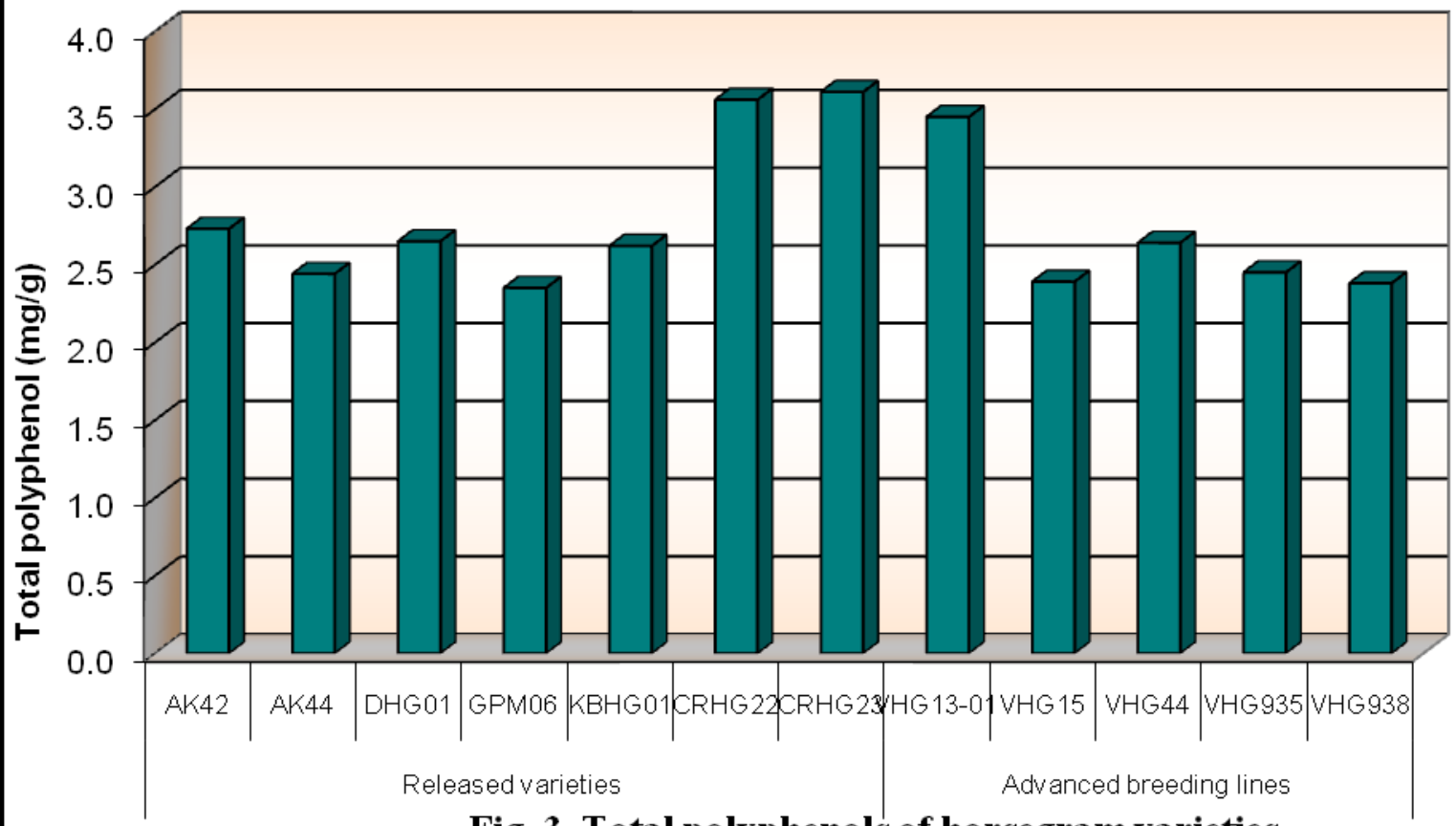

Fig. 3. Total polyphenols of horsegram varieties 
Figure 3 depicts the total polyphenol content of horsegram varieties. Total polyphenol content varied significantly $(\mathrm{p} \leq 0.01)$ among the varieties. The total polyphenol content varied from 2.35-3.61 mgGAE/g. CRHG23 (3.61 mgGAE/g) had highest total polyphenol content followed by CRHG22 (3.56 mgGAE/g) and VHG13-01 (3.45 mgGAE/g). Lowest total polyphenol content was observed in GPM06 (2.35 mgGAE/g) among the horsegram varieties. Comparison of total polyphenol content of released varieties and advanced breeding lines of horsegram is presented in table 6 . There was no significant difference between the groups for total polyphenol content. Released varieties had higher total polyphenols content (2.85 mgGAE/g) compared to advance breeding lines $(2.66 \mathrm{mgGAE} / \mathrm{g})$ of horsegram varieties. The results of present study were on par with the results of Pal et al., (2015) and Siddhuraju and Manian (2007). The study conducted by Sundaram et al., (2013) had slightly lower phenolic content in horsegram variety.

Table 7 depicts the correlation between total polyphenols and antioxidant activity content of horsegram varieties. The total polyphenol was positively correlated to antioxidant activity. Table 8 depicts the correlation between protein content and antioxidant activity of horsegram varieties. The protein content was positively correlated to antioxidant activity and it was statistically significant $(\mathrm{p} \leq 0.01)$. There was a positive correlation between the total polyphenol to antioxidant activity in horsegram varieties. The reason for higher phenolic content may be due to dark colour and black variety of horsegram (Siddhuraju and Manian, 2007) and it also related to higher antioxidant activity.

In conclusion, there was no significant difference among the varieties for crude protein, whereas in vitro protein digestibility, antioxidant activity and total polyphenol content varied significantly ( $\mathrm{p} \leq 0.01)$ among the varieties. When horsegram were compared between the groups i.e., released varieties and advanced breeding lines, there was no significant difference between the groups for crude protein and antioxidant activity whereas there was a significant difference $(p \leq 0.01)$ for in vitro protein digestibility and total polphenol content. Advanced breeding lines had higher values for crude protein, in vitro protein digestibility, antioxidant activity whereas released varieties had higher values for total polphenol content. The protein content of horsegram varieties ranged from $23.10-28.21 \mathrm{~g} / 100 \mathrm{~g}$ and in vitro protein digestibility ranged from 50.80-67.80 per cent. Highest protein content and in vitro protein digestibility was observed in VHG44 and VHG13-01. As horsegram is a underutilized legume and rich in nutrient, it can be utilized in product formulation. Advanced breeding lines had better nutrient composition i.e, protein, in vitro protein digestibility, antioxidant activity and total polyphenol content than released varieties.

\section{Acknowledgment}

The data presented in the article is part of M.H.Sc. thesis by the first author to the University of Agricultural Sciences, Dharwad, and Karnataka, India.

\section{References}

Amarowicz, R. and Pegg, R. B., 2008, Legumes as a source of natural antioxidants. European J. Lipid Sci. Technol., 110: 865-878.

Anonymous, 2005, Official Methods of Analysis, Association of Official Analytical Chemists, $18^{\text {th }}$ edition, Washington, D. C., USA.

Bhartiya, A., Aditya, J. P. and Kant, L., 2015, Nutritional and remedial potential of an 
underutilized food legume horsegram (Macrotyloma uniflorum): A review. $J$. Anim. Plant Sci., 25(4): 908-920.

Bhokre, C. K. and Joshi, A. A., 2015, Effect of soaking on physical functional and cooking time of cowpea, horsegram and mothbean. Food Sci. Res. J., 6(2): 357362.

Bhokre, C. K., Joshi, A. A. and Rodge, A. B., 2015, Determination of physicochemical and functional properties of different genotypes of horsegram. Asian J. Dairy Food Res., 34(4): 307-313.

Durga, K. K., 2016, Variability and divergence in horsegram (Dolichos uniflorus). J. Arid Land., 4(1): 71-76.

Hiremath, J., Sharan, S. and Vishwanath, K. P., 2001, Chemical composition and functional properties of some important genotypes of horsegram (Macrotyloma uniflorum Lam Verdc.). Karnataka J. Agric. Sci., 14(4): 943-946.

Khatoon, N. and Prakash, J., 2005, Nutrient retention in microwave cooked germinated legumes. Food Chem., 97(1): 115-121.

Kris-Etherton, P. M., Heckar, K. D., Bonanome, A., Coval, S. M., Binkoski, A. E. and Hilpert, K. F., 2002, Bioactive compounds in foods: their role in the prevention of cardiovascular disease and cancer. The American J. Medicine., 113: 715-885.

Moulishwar, P., Kurien, S., Daniel, V. A., Malleshi, N. G. and Roa, V., 1993, In vitro digestibility of protein and starch of energy food and its bulk reduction. $J$. Food Sci. Technol., 30(1): 36-39.

Pal, R. S., Bhartiya, A., Arunkumar, R., Kant, L. and Aditya, J. P., 2015, Impact of dehulling and germination on nutrients, antinutrients and antioxidant properties in horsegram. J. Food Sci. Nutr., DOI 10.1007/s13197-015-2037-3.

Roy, F., Boye, J. I. and Simpson, B. K., 2010, Bioactive proteins and peptides in pulse crops: Pea, chickpea and lentil. Food Res. Int., 43: 432-442.

Sadashivam, S. and Manicham, A., 2008, Biochemical Methods. New Age International Publishers, New Delhi, India.

Siddhuraju, P and Manian, S., 2007, The antioxidant activity and free radicalscavenging capacity of dietary phenolic extracts from horsegram (Macrotyloma uniflorum (Lam.) Verdc.) seeds. J. Food Chem., 105: 950-958.

Sreerama, Y. N., Sasikala, V. R. and Pratape, V. M., 2008, Nutritional implications and flour functionality of popped/expanded horsegram. Food Chem., 108: 891-899.

Sundaram, U., Marimuthu, M., Anupama, V. and Gurumoorthi, P., 2013, Comparative antioxidant quality evaluation of underutilized/less common south Indian legumes. Int. J. Pharm. Bio. Sci., 4(2): 117-126.

\section{How to cite this article:}

Aishwarya V. Patil and Kasturiba, B. 2019. A Study on Protein, in vitro Protein Digestibility, Antioxidant Activity and Total Polyphenol Content of Horsegram Varieties. Int.J.Curr.Microbiol.App.Sci. 8(02): 1936-1944. doi: https://doi.org/10.20546/ijcmas.2019.802.225 